Check for updates

Cite this: RSC Adv., 2017, 7, 40873

\title{
The anti-cancer potency of photodynamic therapy of a novel chlorin derivative Amidochlorin p6 (ACP)
}

\author{
Hongyue Zhang, ${ }^{a}$ Wenting Li, ${ }^{a}$ Guanghui Tan, ${ }^{b}$ Guohua Ding, ${ }^{\text {bb }}$ Zhiqiang Wang*a \\ and Yingxue Jin (iD *a
}

Photodynamic therapy (PDT) is a minimally invasive method in cancer treatment and has attracted considerable attention recently. In this paper, we have performed a detailed study of photodynamic activity of a chlorophyllous derivative, Amidochlorin p6 (ACP), and evaluated its potential as a photosensitizer in PDT. The singlet oxygen quantum yield $\left(\Phi_{\Delta}\right)$, the photoreaction mechanisms in PDT, the anti-photobleaching ability in phosphate buffer saline (PBS), the photocytotoxicity and dark toxicity against HeLa cells, cellular uptake and the influence on the expression of survivin and cyclin-dependent kinase (CDK2), were all investigated. The title compound showed significant photocytotoxicity and negligible toxicity in dark, and remarkable photostability. Moreover, ACP could be uptaken by HeLa cells successfully at 20 min leading to damage of cancer cells under light, during which Type I and Type II photodynamic reactions occurred simultaneously on HeLa cells in PDT treatment, and the influence of Type I (the generation of hydroxyl radicals) is slightly larger than Type II (the generation of singlet oxygen). In addition, real-time fluorescent quantitative PCR (RT-qPCR) suggested that ACP could significantly regulate the expression of survivin, which partly explained why ACP could induce the HeLa cell apoptosis and accelerate cell death.

Received 4th July 2017

Accepted 16th August 2017

DOI: $10.1039 / \mathrm{c} 7 \mathrm{ra0} 07368 \mathrm{~b}$

rsc.li/rsc-advances and low toxic PSs. Among various PSs under development, chlorophylls have aroused widespread attention. For example, chlorin e6 (Ce6), a promising PS in phase II clinical trial, is one of chlorophyll degradation products, which has the advantage of single chemical component, definite chemical structure, long-wavelength absorption at $660 \mathrm{~nm} ;{ }^{12}$ a derivative of Ce6, single aspartyl Ce6 ( $N$-aspartyl chlorin Npe6) also showed promising potential in PDT due to the high singlet oxygen yield, short retention time, fast clearance and hardly causing photosensitive skin side effects. ${ }^{13}$ Moreover, 2-[1-hexyloxyethyl]-2devinyl pyropheophorbide- $a$ (HPPH), which is a second generation PS, has been progressed through phase II clinical trials, showing excellent safety and efficacy for the treatment of lung, head and neck cancers. ${ }^{14}$

Our group have devoted to synthesizing chlorophyll derivatives and preparing the PSs for PDT application. ${ }^{15-19}$ In our previous work, we had reported a novel chlorophyll derivative with two hydroxyl groups at $\mathrm{C}-13^{5}, 15^{6}$ named Amidochlorin p6 (ACP), which showed excellent potential in $\mathrm{Cu}^{2+}$ detection ${ }^{20}$ (Fig. 1). Considering that ACP has two hydroxyl groups in its structure, it may improve the water solubility. Moreover, the structure of ACP and the absorption of long-wavelength absorption are similar to those of Ce6, hence it may exhibit promising photodynamic activity. Therefore, in this paper, we try to systematically study the photophysical properties of ACP, including singlet oxygen quantum yield $\left(\Phi_{\Delta}\right)$ and photostability. Moreover, we have performed a detailed bioactivity test of ACP
${ }^{a}$ Ministry of Education, Key Laboratory of Photochemical Biomaterials and Energy Storage Materials, Harbin Normal University, Harbin, 150025, China. E-mail: jyxprof@163.com; wzq70402@163.com

${ }^{b}$ College of Life Science and Technology, Harbin Normal University, Harbin, 150025, China. E-mail: dghprof@163.com 


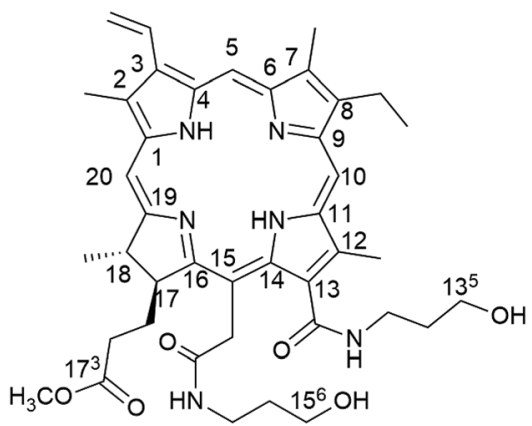

Fig. 1 The structure and atom numbers of Amidochlorin p6 (ACP).

against HeLa cells, including phototoxicity, dark toxicity, the mechanism of photodynamic reaction, cellular uptake and the changes of cell morphology after PDT. Finally, to further study the mechanism of PDT, we have successfully extracted the total cellular RNA from HeLa cells treated with ACP and investigated the expression of survivin and cyclin-dependent kinase 2 (CDK2) in HeLa cells.

\section{Materials and methods}

\section{General information}

Dimethyl sulfoxide (DMSO) and N,N-dimethylformamide (DMF) were obtained from Sinopharm Chemical Reagent (Shanghai, China). Other chemical reagents were obtained from Alfa Aesar (Tianjin, China). All solvents and reagents were analytically pure without further purification. 4,6-Diamidino-2-phenylindole (DAPI), sodium azide (SA), D-mannitol (DM), methylene blue (MB), 1,3-diphenylisobenzofuran (DPBF) and 6-well or 96-well plates were bought from Sigma-Aldrich (Beijing, China). Dulbecco's Modified Eagle Medium (DMEM), fetal bovine serum (FBS), phosphate buffer saline (PBS), 3-(4,5-dimethy lthiazol-2-yl)-2,5dipheny-ltetrazolium bromide (MTT), ethidium bromide (EB), penicillin and streptomycin were bought from Gibco (Shanghai, China). UV-vis absorption was recorded using a UV-160A spectrophotometer (Shimadzu, Kyoto, Japan). All measurements were performed at room temperature (about $25{ }^{\circ} \mathrm{C}$ ), unless otherwise stated. All spectra were obtained in a quartz cuvette (path length $=$ $1 \mathrm{~cm}$ ). Xenon Lamp (HSX-UV300) passed through a band-pass $670 \pm 10 \mathrm{~nm}$ filter (DT670 quartz filter, NBeT, Beijing, China) to supply the near infrared light in the range of 660-680 $\mathrm{nm}$. Human cervical cell lines (HeLa) were purchased from Sigma-Aldrich. The viability of HeLa cells was measured by MTT assay and recorded on enzyme-linked immunosorbent assay reader, Synergy II, BioTek, VT. All the confocal images were obtained utilizing a Leica DM IL LED fluorescence inverted microscope (FIM, Germany). RNA pure Tissue\&Cell Kit, PrimeScript ${ }^{\mathrm{TM}}$ 1st Strand cDNA Synthesis Kit and UltraSYBR One Step RT-qPCR Kit (High ROX) were purchased from Kang century Biotechnology (Beijing, China).

\section{Preparation of ACP and stock solutions of ACP}

ACP was prepared according to our previous reported procedure. ${ }^{20}$ The concentration of stock solutions of ACP applied in bio- experiments was $25 \mathrm{mmol} \mathrm{L}^{-1}$ in DMSO, which was redistributed in DMEM without any nutrient to obtain the required concentrations for MTT assay. For the other bio-experiments (such as RNA extract, cellular uptake and morphology changes), the samples were prepared as above using $8 \mathrm{mmol} \mathrm{L}^{-1}$ stock solutions of ACP. The final DMSO concentration in all the samples was $<0.1 \%$.

\section{Detection of singlet oxygen quantum yield of ACP}

To detect ${ }^{1} \mathrm{O}_{2}$ generation during the exposure to light for 0-120 s, DPBF was used as trapping reagent. Methylene blue (MB) was used as the reference compound, the singlet oxygen quantum yield $\left(\Phi_{\Delta}\right)$ of which in DMF is $49.1 \% .^{21} 3 \mathrm{~mL}$ stock solution of DPBF in DMF $\left(6 \times 10^{-5} \mathrm{~mol} \mathrm{~L}^{-1}\right)$ containing $20 \mu \mathrm{L}$ PSs solution (the concentration of ACP and MB were $2.8 \times$ $10^{-6} \mathrm{~mol} \mathrm{~L}^{-1}$ ) was placed in a quartz cuvette and irradiated with light for different periods of time at room temperature. The absorption spectra of the solution at $415 \mathrm{~nm}$ were monitored every $10 \mathrm{~s}$ for a $120 \mathrm{~s}$ period. The singlet oxygen quantum yield $\left(\Phi_{\Delta}\right)$ of ACP was calculated using the following formula:

$$
\Phi_{\Delta}(\mathrm{S})=\frac{\Phi_{\Delta}(\mathrm{R}) k^{\mathrm{S}} I_{a T}(\mathrm{R})}{k^{\mathrm{R}} I_{a T}(\mathrm{~S})}
$$

$$
I_{\mathrm{a}}=I_{0}\left(1-\mathrm{e}^{-2.3 A}\right)
$$

superscript $\mathrm{S}$ and $\mathrm{R}$ respect the sample and reference compound, respectively. $I_{\mathrm{a}}$ is defined as the total amount of light absorbed by PSs. $A$ is the corresponding absorbance at irradiation wavelength. $k$ is a slope of a plot of the dependence of $\ln \left(A_{0} / A_{t}\right)$ on irradiation time $t$, with $A_{0}$ and $A_{t}$ being the absorbance of the DPBF at $415 \mathrm{~nm}$ before irradiation and after irradiation time $t(\mathrm{~s})$, respectively. ${ }^{22}$

\section{Anti-photobleaching ability of ACP}

The concentration of ACP was $1 \times 10^{-5} \mathrm{~mol} \mathrm{~L}^{-1}$ in PBS. Appropriate blanks corresponding to the PBS were subtracted to correct the background. Before irradiation, ACP solution was transferred to a $1 \times 1 \mathrm{~cm}$ glass cuvette to record the absorbance of ACP at long-wavelength absorption. Light irradiates vertically on the solution surface of the glass cuvette every ten minutes. The absorption spectrum of ACP was recorded with UV-vis spectrometer at $10 \mathrm{~min}$ intervals for a period of $60 \mathrm{~min}$. All the operations were carried out at room temperature. The curves of absorbance of ACP at each time point against irradiating time were drawn. The percentage of ACP was calculated by the following formula:

$$
\text { Percentage of ACP }(\%)=\frac{A_{t}}{A_{0}} \times 100 \%
$$

$A_{0}, A_{t}$ are the absorbance measured before irradiation and after irradiation $t$ seconds, respectively.

\section{Cell culture}

Human cervical carcinoma cell line (HeLa) was routinely maintained in Dulbecco's Modified Eagle Medium (DMEM) 
containing $100 \mu \mathrm{g} \mathrm{mL}{ }^{-1}$ penicillin, $100 \mu \mathrm{g} \mathrm{mL} \mathrm{m}^{-1}$ streptomycin and $10 \%$ fetal bovine serum (FBS). HeLa cells were grown at $37{ }^{\circ} \mathrm{C}$ under an atmosphere of $5 \% \mathrm{CO}_{2}$. The cells in logarithmic phase were applied into 6-well or 96-well plates for further use after dissociation and suspension adherent growth $24 \mathrm{~h}$.

\section{Cytotoxicity and MTT assay}

HeLa cells were seeded in 96-well cell culture plates at a density of $4 \times 10^{3}$ cells per well at $37{ }^{\circ} \mathrm{C}$ and $5 \% \mathrm{CO}_{2}$. After overnight incubation, cells were incubated with ACP at different concentrations $\left(0.195,0.39,0.78,1.56,3.12,6.25,12.5,25 \mu \mathrm{g} \mathrm{mL}{ }^{-1}\right)$ at $37{ }^{\circ} \mathrm{C}$ for $4 \mathrm{~h}$, followed by irradiation with light $\left(5 \mathrm{~mW} \mathrm{~cm}{ }^{-2}\right.$, $10 \mathrm{~min}$ ). Then, $20 \mu \mathrm{L} \mathrm{MTT}\left(5 \mathrm{mg} \mathrm{mL}^{-1}\right)$ were added in each wells after $24 \mathrm{~h}$. After $4 \mathrm{~h}$ of incubation with MTT, the media were removed and $150 \mu \mathrm{L}$ DMSO were added to solubilize the formazan crystals. The cell viability was measured with enzymelinked immunosorbent assay reader at an absorbance of $570 \mathrm{~nm}$. To evaluate dark toxicity, the cells were treated with ACP under the same conditions but without the light exposure.

\section{Cell uptake}

Cellular uptake of ACP was investigated by FIM. HeLa cells were seeded into 6 -well cell culture plates $\left(1 \times 10^{5}\right.$ cells per well $)$ and incubated for $24 \mathrm{~h}$. The cells were incubated with ACP $\left(8 \mu \mathrm{g} \mathrm{mL}{ }^{-1}\right)$ at $37{ }^{\circ} \mathrm{C}$ for $0,20,40,60,120,180 \mathrm{~min}$. Cells were washed with PBS three times and fixed with $4 \%$ paraformaldehyde for $10 \mathrm{~min}$. Then, cells were again washed with PBS three times and stained with $1 \mathrm{mg} \mathrm{mL}^{-1}$ DAPI for $10 \mathrm{~min}$.

\section{The photoreaction process of ACP}

HeLa cells were seeded into 96-well plates at a density of $4 \times 10^{3}$ cells per well. D-mannitol (DM) and sodium azide (SA) are quenchers which could trap the hydroxyl radical $\left({ }^{\circ} \mathrm{OH}\right)$ quencher and singlet oxygen $\left({ }^{1} \mathrm{O}_{2}\right)$ generated by photosensitizer during irradiation. The tests were divided into three groups: ACP-PDT; ACP-DM-PDT and ACP-SA-PDT. The cells of the ACP-PDT groups were treated with PS. ACP-DM-PDT groups and ACP-SA-PDT groups were treated with PS and quenching agent DM $\left(20 \mu \mathrm{L}, 40 \mathrm{mmol} \mathrm{L}^{-1}\right)$ or SA $\left(20 \mu \mathrm{L}, 20 \mathrm{mmol} \mathrm{L}^{-1}\right)$, respectively. The final concentrations of ACP were 0.195, 0.39, $0.78,1.56,3.12,6.25,12.5,25 \mu \mathrm{g} \mathrm{mL}{ }^{-1}$, respectively. After additional $4 \mathrm{~h}$ of incubation with samples, all wells were exposed to light for $10 \mathrm{~min}$. The plates were then kept in the incubator for additional $24 \mathrm{~h}$. Then, cell viability was estimated by MTT assay, as described above. Each experiment was paralleled three times.

\section{Cell morphology observation}

To study the changes of cellular morphology after PDT, cells were incubated into six-well plates $\left(1 \times 10^{5}\right.$ cells per well $)$ with $1 \mathrm{~mL}$ DMEM. After the cells adhered to the plate, the DMEM medium was removed and the cultures were washed three times with PBS. Then add $1 \mathrm{~mL}$ ACP $\left(8 \mu \mathrm{g} \mathrm{mL}^{-1}\right)$ solution in each wells, which were then incubated for $4 \mathrm{~h}$, followed by the irradiation $\left(10 \mathrm{~min}, 5 \mathrm{~mW} \mathrm{\textrm {cm } ^ { - 2 }}\right)$. After irradiation, cells were cultured another $0 \mathrm{~h}, 6 \mathrm{~h}, 12 \mathrm{~h}, 24 \mathrm{~h}$, the solution was removed and ACP was rinsed three times with PBS. The cell morphological changes were analyzed by FIM.

\section{RNA extraction}

Collect the cells after ACP-PDT at different time (0, 6, 12, $24 \mathrm{~h})$. The total cellular RNA of HeLa cells were extracted using a RNA pure Tissue\&Cell Kit according to the manufacturer's instructions. The products were separated by $1 \%$ agarose gel electrophoresis, stained with EB, and visualized using UV light. The experiment was repeated for three times. All samples were subjected to DNase treatment to avoid DNA contamination, followed by reverse transcription (RT) using a PrimeScript ${ }^{\mathrm{TM}} 1 \mathrm{st}$ Strand cDNA Synthesis Kit. The products above could be subjected to the next step at once or preserved at $-20{ }^{\circ} \mathrm{C}$.

\section{Detection of real-time fluorescent quantitative PCR}

Apoptosis-related gene (survivin) and cell cycle-related gene (CDK2) expression levels were quantified by real-time fluorescent quantitative PCR (RT-qPCR). Primer glyceraldehyde 3-phosphate dehydrogenase (GAPDH) was used as reference, in which the levels of each mRNA were normalized relative to the quantity of human GAPDH in each cell. ${ }^{23}$ The RT-qPCR was performed by UltraSYBR One Step RT-qPCR Kit (High ROX) according to the manufacturer's instructions. The reaction procedure of RT-qPCR is as follows: 40 cycles of denaturation at $95{ }^{\circ} \mathrm{C}$ for $30 \mathrm{~s}$, primer annealing at $56{ }^{\circ} \mathrm{C}$ for $30 \mathrm{~s}$, and extension at $72{ }^{\circ} \mathrm{C}$ for $1 \mathrm{~min}$. All experiments were done 4 times. All the PCR products which had been recovered and sequenced were contrasted with the design of primers and probe sequences to analysis effect of primer amplification.

\section{Statistical analysis}

All the results were expressed as the mean \pm SD of three independent experiments. Statistical analysis was performed using Student's $t$-test using the SPSS 19.0, and $p<0.05$ was considered statistically significant.

\section{Results and discussion}

\section{The UV-vis absorption and singlet oxygen detection of ACP}

Fig. 2a displayed the UV-vis absorption spectra of ACP $(c=1 \times$ $10^{-5} \mathrm{~mol} \mathrm{~L}^{-1}$ ) in DMF and PBS. In DMF, ACP absorbed throughout the UV-vis region between about 300 and $800 \mathrm{~nm}$ with four peaks: a strong Soret absorption peak at $401 \mathrm{~nm}$, three weak absorption peaks at $500 \mathrm{~nm}, 529 \mathrm{~nm}$ and $608 \mathrm{~nm}$, and a $Q(0,0)$ band at $663 \mathrm{~nm}$, showing typical absorption characteristics of chlorophylls. Meanwhile, the spectrum of ACP in PBS also showed a strong absorption Soret band at $400 \mathrm{~nm}$ and a $Q(0,0)$ band at $660 \mathrm{~nm}$, displaying a $3 \mathrm{~nm}$ blue-shift compared with that in DMF.

Before a novel PS is used as a candidate for PDT agent, it is of great important to measure the ${ }^{1} \mathrm{O}_{2}$ quantum yield $\left(\Phi_{\Delta}\right)$. It is known that DPBF could be oxidized rapidly into $o$-dibenzoylbenzene at the present of ${ }^{1} \mathrm{O}_{2}$ via a ring opening reaction, meanwhile the intensity of DPBF characteristic peak (415 nm) 

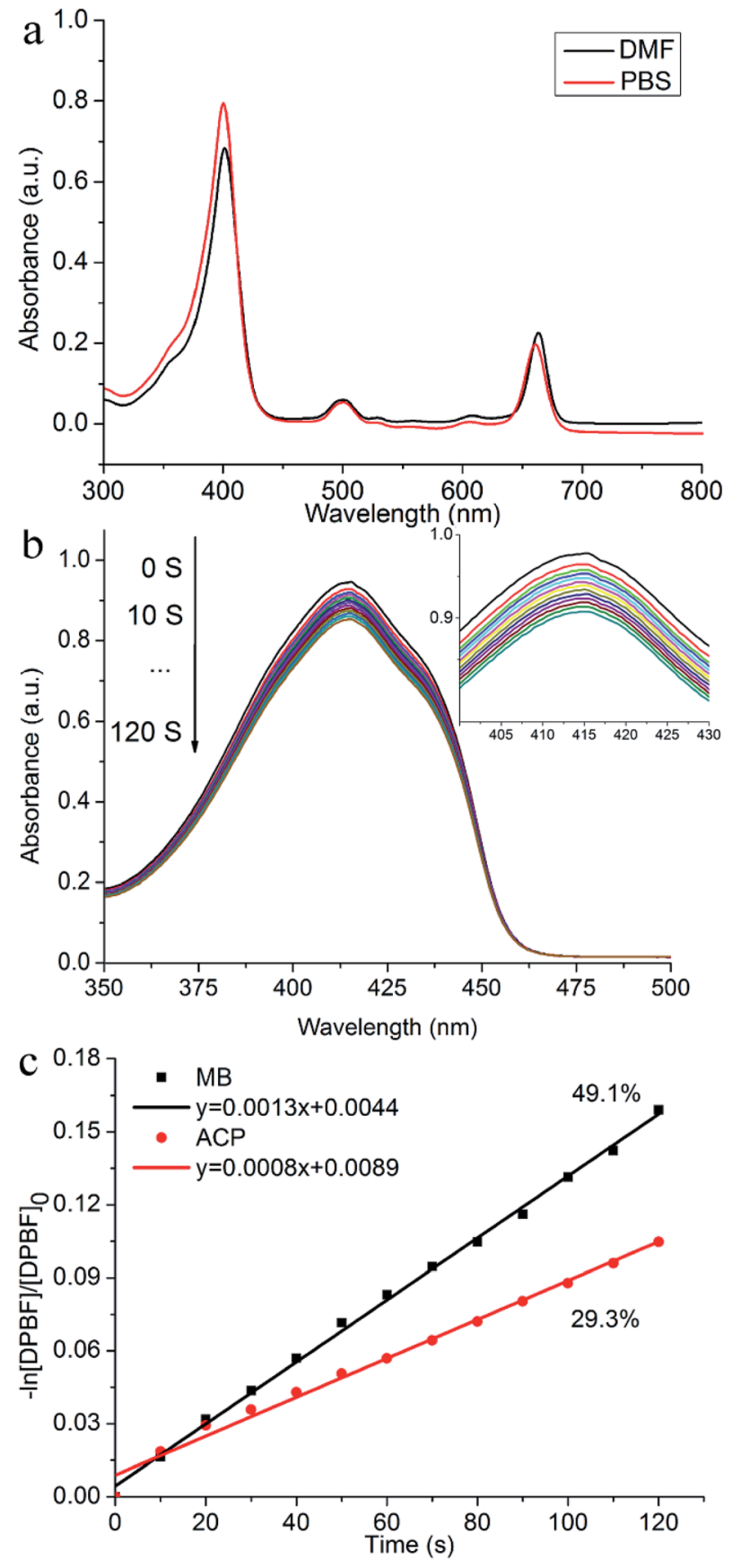

Fig. 2 (a) The UV-vis absorption spectra of ACP (the concentration of ACP is $1 \times 10^{-5} \mathrm{~mol} \mathrm{~L}^{-1}$ ) in DMF and PBS. (b) UV-vis absorption spectra of decomposition of DPBF after irradiation of ACP in DMF. (The inset is a locally enlarged drawing of (b); (c) first-order plots for the photodecomposition of DPBF monitoring the long-wavelength absorption of DPBF at $415 \mathrm{~nm}$.

was degraded, ${ }^{24}$ which corresponds to the ability of PSs to produce singlet oxygen. To observe the process of dynamic quenching of ROS and avoid PSs interfering the absorption of DPBF at $415 \mathrm{~nm}$, we set a very low concentration of PS $(2.8 \times$ $\left.10^{-6} \mathrm{~mol} \mathrm{~L}^{-1}\right)$ and a relative high concentration of DPBF $(6 \times$ $10^{-5} \mathrm{~mol} \mathrm{~L}^{-1}$ ), because the PS absorbed very little at the low concentration, therefore it can be corrected as background of

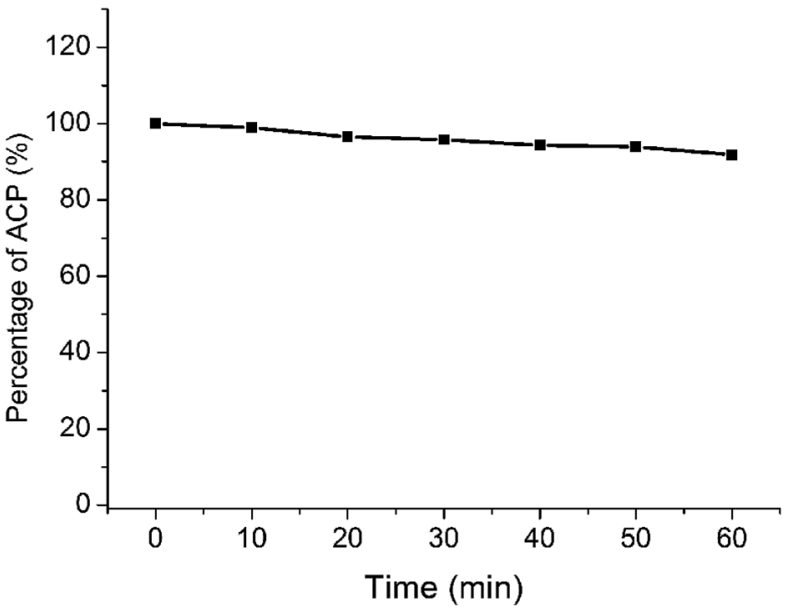

Fig. 3 The photobleaching plot based on the absorption in PBS.

absorbance and the absorption of PSs would not affect the absorption of DPBF at $415 \mathrm{~nm}$. As shown in Fig. 2a, the absorption of DPBF in DMF at $415 \mathrm{~nm}$ gradually decreased from $0 \mathrm{~s}$ to $120 \mathrm{~s}$, indicating that the target compound could generate the ${ }^{1} \mathrm{O}_{2}$ under the light. The slope of ACP and MB was obtained after fitting with a linear function $\left(R^{2}>0.9983\right)$. The singlet oxygen quantum yield $\left(\Phi_{\Delta}\right)$ of ACP in DMF is $29.3 \%$ (Fig. 2 b), exhibiting that ACP has promising ability to produce singlet oxygen after irradiation.

\section{Photobleaching test of ACP}

Photobleaching can reduce the yield of reactive oxygen species (ROS) and decrease the ability to destroy tumors. ${ }^{25}$ In PDT, photobleaching refers to the phenomenon of degradation of PS under light. ${ }^{26}$ Photobleaching is inevitable in the PDT process with the formation of singlet oxygen. The therapeutic effect of PDT is related to the amount and the rate of photobleaching. ${ }^{27}$ Therefore, the anti-photobleaching ability of photosensitizer was an important parameter of PDT. In this paper, the longwavelength absorption of ACP was $660 \mathrm{~nm}$ in PBS, which was used to calculate the photobleaching rate. As shown in Fig. 3, ACP showed a slow trend of degradation over the time. The photobleaching rate was $1.1 \%$ at $10 \mathrm{~min}$, which could be ignored. At the endpoint of irradiation, only $8.2 \%$ of ACP was photobleached in PBS. Generally, the photosensitizer could achieve good PDT effects after being exposed to light for $10 \mathrm{~min}$, therefore the photobleaching of ACP has little influence to PDT effects. All in all, ACP showed a very satisfactory photostability during 10 min by irradiation, which could be used as a potential photosensitizer in PDT.

\section{Photodynamic therapy activities of ACP}

The cytotoxicity of the title compound against HeLa cells was shown in Fig. 4, in which red columns and black columns stand for the cell viability of HeLa cells treated with ACP with and without light, respectively. The control groups treated with different concentrations of ACP in the dark showed high cell viability (>90\%), indicating that the dark toxicity of ACP was 


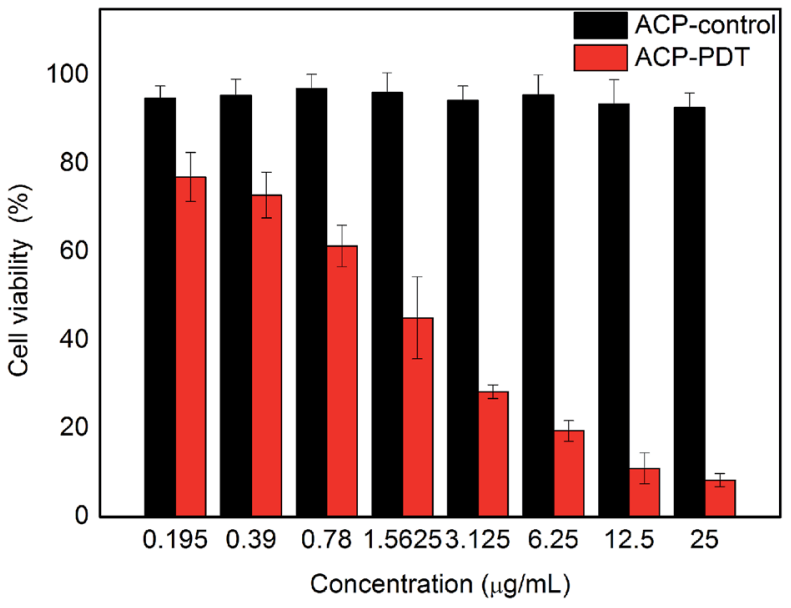

Fig. 4 The photodynamic activity of the ACP against HeLa cells after $24 \mathrm{~h}$.

negligible on HeLa cells without light. The cell viability of ACP-PDT declined gradually with increasing concentration of ACP under light. With a $10 \mathrm{~min}$ irradiation, $0.78 \mu \mathrm{g} \mathrm{mL} \mathrm{m}^{-1}$ of ACP could cause approximately $39 \%$ cell mortality. When the concentration of ACP was up to $6.25 \mu \mathrm{g} \mathrm{mL} \mathrm{m}^{-1}$, the cell viability decreased to $19 \%$, suggesting that ACP had a strong cytotoxicity on HeLa cells. The cytotoxicity against HeLa cells of pyropheophorbide- $a(\mathrm{PPa})$ and Ce6 were conducted in parallel in our laboratory, which suggested that the title compound showed a stronger cytotoxicity (the cell viability was $21 \%$ at the concentration of $8 \mu \mathrm{mol} \mathrm{L}^{-1}$ ) than PPa (cell viability, 38\%) and Ce6 (cell viability, 61\%) at the same conditions (10 min irradiation, $5 \mathrm{~mW} \mathrm{~cm}^{-2}$ ). Based on the above analysis, our proposed compound is an excellent candidate in PDT drug development.

\section{The photoreaction process of ACP after PDT}

The excited PS could produce reactive oxygen species (ROS) by two ways that induced the tumor necrosis or apoptosis, that is, Type I process involving generation of hydroxyl radicals (HR) and other reactive oxygen species; Type II process involving generation of singlet oxygen $\left({ }^{1} \mathrm{O}_{2}\right) .{ }^{28}$ To investigate the type of photochemical reaction of ACP, sodium azide (SA, a quencher of ${ }^{1} \mathrm{O}_{2}$ ) and D-mannitol (DM, a quencher of hydroxyl radical) were introduced.$^{29}$ Fig. 5 showed the cell viability of the three experimental groups: ACP-PDT, ACP-DM-PDT and ACP-SAPDT. With the quenching agent's adding, the cell viability of ACP-DM-PDT and ACP-SA-PDT increased typically, demonstrating that corresponding reactive oxygen species were quenched and also indicating that the ROS were generated in HeLa cells treated with ACP during the light. Meanwhile, the mechanism of generating ROS against HeLa cells in PDT treatment may be performed via two ways, Type I and Type II photodynamic reaction. Moreover, the cell viability of the ACP-DM-PDT groups were slightly higher than the cell viability of ACP-SA-PDT groups, from which we can conclude that the generation of hydroxyl radicals play a more important role than that of singlet oxygen in PDT. Herein, this partly explained why

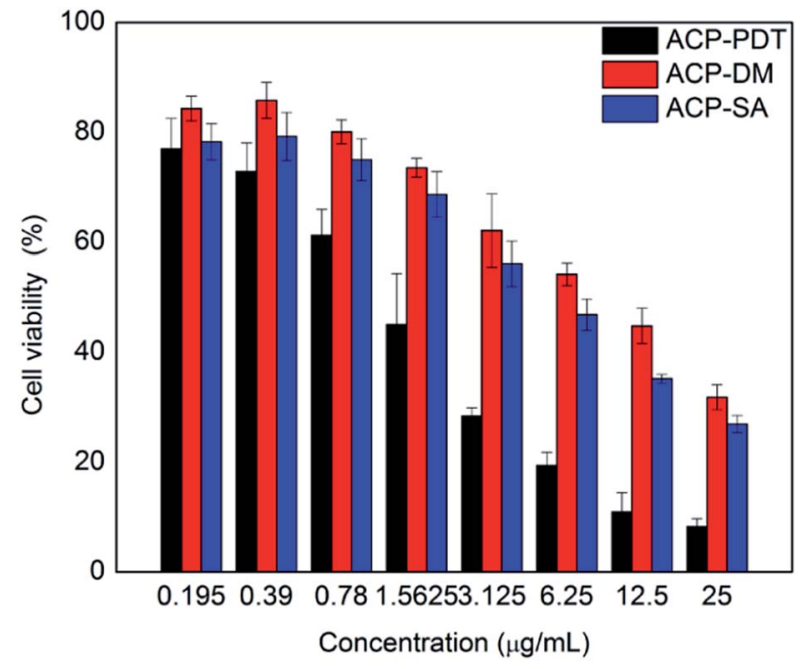

Fig. 5 Cell viability of three groups on the HeLa cells. ACP-PDT stands for the groups treated with ACP under irradiation. ACP-DM-PDT stands for the groups treated with $A C P$ and $D$-mannitol under irradiation; ACP-SA-PDT stands for the groups treated with ACP and sodium azide under irradiation.

the cytotoxicity of target compound was remarkable, but singlet oxygen quantum yield $\left(\Phi_{\Delta}\right)$ of ACP $(29.3 \%)$ was not very high in DMF.

\section{Cell uptake of ACP}

Reasonable ability to penetrate the cell membrane would make the photosensitizer more efficient. ${ }^{30}$ To further validates the potential in clinical application, we have investigated the uptaking of HeLa cells against ACP in vitro. To identify the intracellular uptake of ACP, HeLa cells were stained with 4,6-diamidino-2-phenylindole (DAPI), which is extensively used nuclear stain agent showing blue fluorescence. ACP would emit red fluorescence under FIM. As shown in Fig. 6, the fluorescence intensity of ACP showed time-dependent increase. After incubated with ACP for $20 \mathrm{~min}$, some HeLa cells with red fluorescence were observed, suggesting partial ACP has been uptaken by the cells. Cell treated with ACP for 40 min displayed the enhanced fluorescence signal, implying that more PS entered the cells. The red signal became brighter and brighter over the time, suggesting that the photosensitizer (ACP) had a good ability to entering HeLa cells. Moreover, from the image of overlay, it had been confirmed that ACP could accumulate and distribute in cytoplasm of HeLa cells.

\section{Cell morphology observation}

The changes of cell morphology in bright field were analyzed by fluorescence inverted microscope (FIM) after irradiation for 0 , $6,12,24 \mathrm{~h}$, respectively. As shown in Fig. $7 \mathrm{a}(0 \mathrm{~h})$, the HeLa cells morphology were spindle-shaped and closely linked to each other. All the cells maintained normal cell morphology and grew adherent to the plate with steady cytoplasm and high refractive index. As the passage of time, cells became rounder, the cell gap became larger and the membrane became fuzzy 


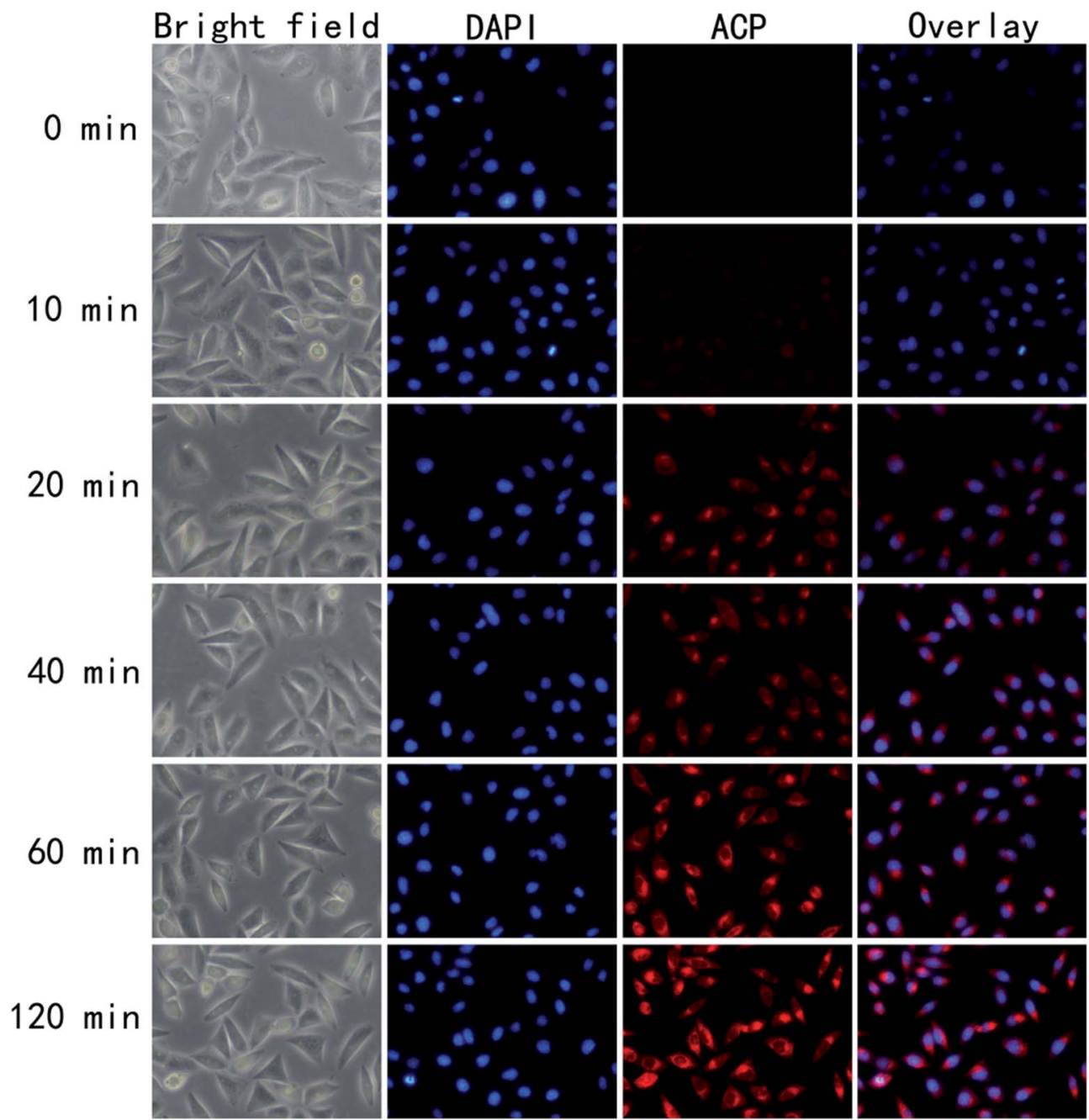

Fig. 6 In vitro uptake of ACP was observed by fluorescence inverted microscopic after incubating HeLa cells with ACP for 0, 20, 40, 60 and $120 \mathrm{~min}$, respectively. The blue fluorescence was attributed to cell nucleus (stained by DAPI), the red fluorescence was due to ACP and the overlay image in DAPI and ACP channels on the same cell.

with significantly decreased shading degree. After treated with PDT and cultured for additional $6 \mathrm{~h}$ (Fig. 7b), a majority of cells gradually began to rounder and some cells maintain normal cell morphology. The rounder cells had change to an irregular shape and the shading degree slightly decreased, indicating that the efficient PDT activities of ACP to induce cell damage. After prolonged incubation for $12 \mathrm{~h}$ (Fig. 7c), the obviously injury of the cell membrane structure, remarkably pathological changes and significantly decreased shading degree could be observed, showing that HeLa cells undergone apoptosis and damage after treated with PDT. Finally, in Fig. 7d (24 h), the membrane was destroyed completely and the cells were dead. All in all, the cell morphological changes after ACP-PDT treatment implying that ACP had a efficiently PDT activity to induce apoptosis and damage cell death against HeLa cells.

\section{Expression of survivin and CDK-2 in HeLa cells}

The mechanism of apoptosis induced by PDT may be related to the inhibition of the expression of apoptosis regulating proteins, such as survivin, which is a member of the inhibitor of apoptosis proteins (IAP) family. Survivin could inhibit apoptosis, promote cell proliferation and regulate cell mitosis. Its anti-apoptotic effect may be through apoptosis inhibition of caspase-3 to achieve. ${ }^{31}$ If the expression of survivin is inhibited, the expression of caspase- 3 would be promoted directly or indirectly, thereby leading to apoptosis. ${ }^{32}$ Moreover, it is widely acknowledged that cell cycle arrest is an important reason of cell apoptosis. The family of cyclin-dependent kinases (CDKs) are well known in the cell division cycle. Among them, cyclindependent kinase 2 (CDK2) is an important member of the CDKs family, which is believed to be essential to complete G1 and to initiate $\mathrm{S}$ phase. If the expression of CDK2 declined, $\mathrm{S}$ phase would fail to start normally, and the incomplete $S$ phase events would lead to cell death. ${ }^{33}$ Fig. 8a showed the gel electrophoresis of total RNA from HeLa cells after treated with ACP in different time. It can be observed that both 18s and 28s RNA were clearly visible and $28 \mathrm{~s}$ band is two times brighter than $18 \mathrm{~s}$ band, demonstrating that RNA was successfully extracted. 

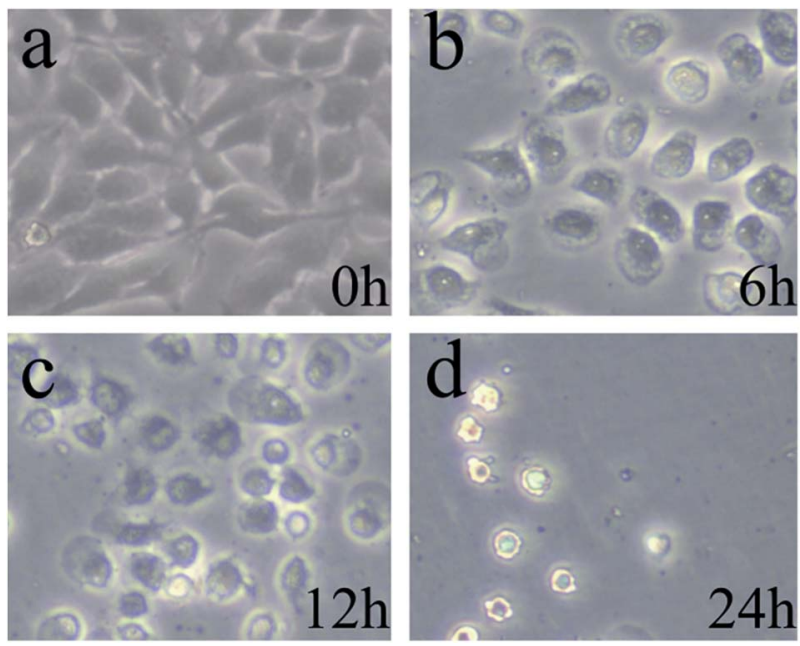

Fig. 7 The cell morphology observation of HeLa cells incubated with $8 \mu \mathrm{g} \mathrm{mL} \mathrm{m}^{-1}$ ACP after PDT for: (a) $0 \mathrm{~h}$; (b) $6 \mathrm{~h}$; (c)12 h; (d) $24 \mathrm{~h}$.

Fig. $8 \mathrm{~b}$ showed the relative expression of survivin and CDK2 under ACP treatment in HeLa cells at $0 \mathrm{~h}, 6 \mathrm{~h}, 12 \mathrm{~h}$ and $24 \mathrm{~h}$, respectively. The expression of survivin in HeLa cells treated with ACP dropped suddenly at $6 \mathrm{~h}$, then increased close to half of the control group at $12 \mathrm{~h}$. Finally it decreased to 0.06 times the size of control group (Fig. 8b). The result indicated that the title compound (ACP) could inhibit the expression of survivin effectively at $6 \mathrm{~h}$ and then accelerate apoptosis. The higher expression of survivin at $12 \mathrm{~h}$ might be due to the cellular stress response to external stimulus. For CDK2 (Fig. 8c), the expression in HeLa cells treated with ACP at $6 \mathrm{~h}$ and $24 \mathrm{~h}$ are 0.8 times and 0.9 times the size of control group, respectively, revealing that the expressions of CDK2 were inhibited after $6 \mathrm{~h}$ and $24 \mathrm{~h}$. The expression of CDK2 is 3.1 times as high as of control group at $12 \mathrm{~h}$, which could be attributed to be cellular stress response, leading a recovery of expression. Based on the above analysis,

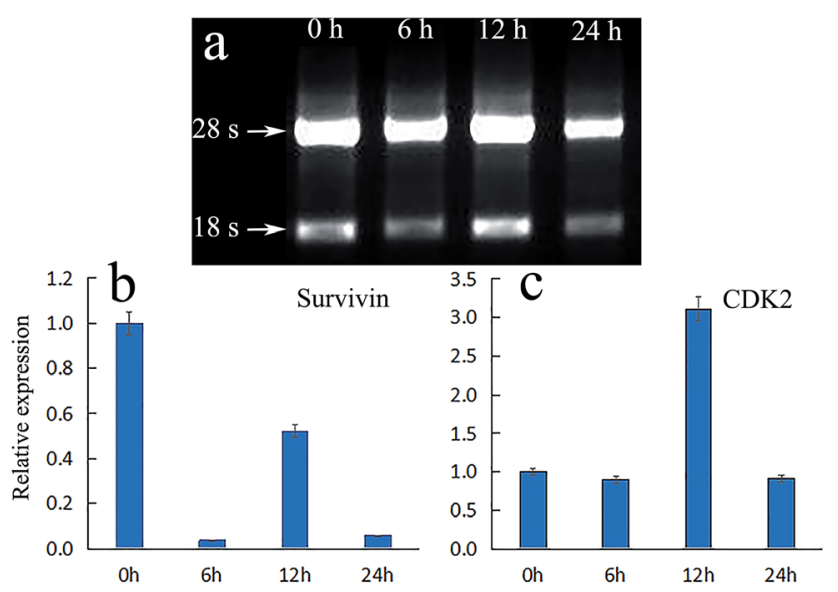

Fig. 8 (a) The gel electrophoresis of total RNA from HeLa cells after treated with ACP in different time. (b and $c$ ). The relative expression of survivin and CDK-2 under ACP treatment in HeLa cells at 0 h, 6 h, 12 h and $24 \mathrm{~h}$.
ACP could inhibited the expression of survivin, result in cells apoptosis and cell death, while the change of expression of CDK2 is negligible after treatment of ACP on HeLa cells.

\section{Conclusion}

In this paper, we have systematically investigated the photodynamic therapy activity of a chlorin derivative Amidochlorin p6 (ACP), which showed excellent phototoxicity against HeLa cells $\left(1.17 \pm 0.029 \mu \mathrm{g} \mathrm{mL}^{-1}, 10 \mathrm{~min}\right.$, dosage $\left.5 \mathrm{~mW} \mathrm{~cm}^{-2}\right)$, negligible dark toxicity, remarkable photostability, and being easily uptaken by cancer cells. Moreover, Type I and Type II photodynamic reactions occurred simultaneously on HeLa cells in PDT treatment, and the influence of Type I was slightly larger than that of Type II. Finally, the RT-qPCR experiment showing that ACP could regulate the expression of survivin, which partly explained why ACP could effectively lead to the cell apoptosis and accelerating cell death. To sum up, ACP is potential as photosensitizer in PDT cancer treatment, and deserves a further investigation.

\section{Conflicts of interest}

There are no conflicts to declare.

\section{Acknowledgements}

Financial support of this research was provided by National Natural Science Foundation of China (No. 21272048), the Natural Science Foundation of Heilongjiang Province (No. B20913), the Program for Scientific Technological Innovation Team Construction in the Universities of Heilongjiang Province (No. 211TD010), the Scientific Research Fund of Heilongjiang Provincial Education Department (No. 12531194), the Natural Science Youth Foundation of Heilongjiang Province (No. QC2016011) and the Innovation Fund for Graduate Students of Harbin Normal University.

\section{References}

1 A. Kamkaew, C. Feng, Y. Zhan, R. L. Majewski and W. Cai, ACS Nano, 2016, 10, 3918-3935.

2 X. Zhuang, X. Ma, X. Xue, Q. Jiang, L. Song, L. Dai, C. Zhang, S. Jin, K. Yang and B. Ding, ACS Nano, 2016, 10, 3486-3496.

3 M. L. Bhaisare, M. S. Khan, S. Pandey, G. Gedda and H. F. Wu, RSC Adv., 2017, 7, 23607-23614.

4 N. Zhou, V. Lópezpuente, Q. Wang, L. Polavarapu, I. Pastorizasantos and Q. H. Xu, RSC Adv., 2015, 5, 2907629097.

5 D. Bůžek, J. Zelenka, P. Ulbrich, T. Ruml, I. Kř́ižová, J. Lang, P. Kubát, J. Demel, K. Kirakci and K. Lang, J. Mater. Chem. B, 2017, 5, 1815-1821.

6 S. Mallidi, S. Anbil, A. L. Bulin, G. Obaid, M. Ichikawa and T. Hasan, Theranostics, 2016, 6, 2458-2487.

7 D. Zhang, S. Yan and W. Song, Environ. Sci. Technol., 2014, 48, 12645-12653. 
8 Z. Z. Yang, M. X. Li, Y. S. Zhang, D. B. Xiang, N. Dai, L. L. Zeng, Z. P. Li, G. Wang and D. Wang, Cancer Sci., 2010, 101, 180-187.

9 M. Leunig, P. Lankes, M. Dellian, A. Leunig, F. Gamarra, J. Feyh and D. M. A. E. Goetz, Lasers Med. Sci., 1992, 7, 477-481.

10 N. Z. Zhang, Y. Zhu, W. Pan, W. Q. Ma and A. L. Shao, Photodiagn. Photodyn. Ther., 2007, 4, 60-64.

11 Q. Peng, T. Warloe, K. Berg, J. Moan, M. Kongshaug, K. E. Giercksky and J. M. Nesland, Cancer, 2010, 65, 235-251.

12 H. Mojzisova, S. Bonneau, P. Maillard, K. Berg and D. Brault, Photochem. Photobiol. Sci., 2009, 8, 778-787.

13 H. Kato, K. Furukawa, M. Sato, T. Okunaka, Y. Kusunoki, M. Kawahara, M. Fukuoka, T. Miyazawa, T. Yana and K. Matsui, Lung Cancer, 2003, 42, 103-111.

14 M. Ethirajan, Y. Chen, P. Joshi and R. K. Pandey, J. Cheminf., 2011, 40, 340-362.

15 J. J. Cheng, G. H. Tan, W. T. Li, J. H. Li, Z. Q. Wang and Y. X. Jin, RSC Adv., 2016, 6, 37610-37620.

16 H. Y. Liu, G. H. Zhu, R. R. Liu, Y. X. Jin, C. X. Qi and J. J. Wang, Chin. J. Org. Chem., 2015, 35, 1320-1329.

17 J. J. Cheng, G. H. Tan, W. T. Li, H. Y. Zhang, S. Y. Li, Z. Q. Wang and Y. X. Jin, J. Nanosci. Nanotechnol., 2017, 17, 4461-4470.

18 X. Y. Yang, S. G. Zhang, P. Zhang, Q. Zhang, Z. Wang, Y. X. Jin, C. X. Qi and J. J. Wang, Chin. J. Org. Chem., 2015, 35, 181-190.

19 G. H. Tan, W. T. Li, J. J. Cheng, Z. Q. Wang, S. Q. Wei, Y. X. Jin, C. H. Guo and F. Y. Qu, Photochem. Photobiol. Sci., 2016, 15, 1567-1578.
20 W. T. Li, G. H. Zhu, J. H. Li, Z. Q. Wang and Y. X. Jin, Molecules, 2016, 21, 107-117.

21 L. J. Zhang, J. Bian, L. L. Bao, H. F. Chen, Y. J. Yan, L. Wang and Z. L. Chen, J. Cancer Res. Clin. Oncol., 2014, 140, 15271536.

22 L. J. Zhang, L. X. Wang, W. L. Zhang, Y. J. Yan and Z. L. Chen, J. Innovative Opt. Health Sci., 2015, 8, 889-900.

23 T. Kushibiki, J. Biophotonics, 2010, 3, 368.

24 L. Rogers, N. N. Sergeeva, E. Paszko, G. M. Vaz and M. O. Senge, PLoS One, 2015, 10, e0125372.

25 Y. Wang, Proc. SPIE, 2010, 7845, 78451I-78458I.

26 T. Bastogne, S. Mézières-Wantz, N. Ramdani, P. Vallois and M. Barberi-Heyob, Eur. J. Control, 2008, 14, 149-157.

27 A. Johansson, F. Faber, G. Kniebühler, H. Stepp, R. Sroka, R. Egensperger, W. Beyer and F. W. Kreth, Lasers Surg. Med., 2013, 45, 225-234.

28 J. J. Cheng, W. T. Li, G. H. Tan, Z. Q. Wang, S. Y. Li and Y. X. Jin, Biomed. Pharmacother., 2017, 87, 263-273.

29 W. T. Li, G. H. Tan, J. J. Cheng, L. S. Zhao, Z. Q. Wang and Y. X. Jin, Molecules, 2016, 21, 558-570.

30 J. J. Cheng, G. H. Tan, W. T. Li, H. Y. Zhang, X. D. Wu, Z. Q. Wang and Y. X. Jin, New J. Chem., 2016, 40, 8522-8534. 31 N. Gulyaeva, Biochemistry, 2003, 68, 1171-1180.

32 S. I. Yamashita, Y. Masuda, T. Kurizaki, Y. Haga, T. Murayama, S. Ikei, M. Kamei, S. Takeno and K. Kawahara, Anticancer Res., 2007, 27, 2803-2808.

33 A. Satyanarayana, M. B. Hilton and P. Kaldis, Mol. Biol. Cell, 2008, 19, 65-77. 